\title{
SISTEM DAN PROSEDUR PELATIHAN DAN PENGEMBANGAN TERHADAP KINERJA KARYAWAN BCA
}

\author{
Ria Anggelina dan Oey Hannes Widjaya \\ Fakultas Ekonomi Universitas Tarumanagara \\ Email: hanneswidjaya@gmail.com
}

\begin{abstract}
Employee performance is banking activities play an important role in maintaining the presence of the Bank's customers. At BCA there are problems between the services provided Employees often do not satisfy the customers as the service is slow, difficult to conduct transactions. The research sample used was non-probability sampling with a sample of 100 employees in PT.BCA. Data analysis techniques used are validity and reliability, test classic assumptions and hypotheses. The results showed that there are significant systems and procedures for employee training and development of the quality of employee performance at PT. BCA with a 95\% confidence level.
\end{abstract}

Keywords: Systems, Procedures, Training, Development, Performance

\begin{abstract}
Abstrak: Kinerja karyawan merupakan aktivitas perbankan yang memegang peranan penting dalam mempertahankan keberadaan nasabah Bank ini. Pada bank BCA terdapat masalah didalam pelayanan yang diberikan Karyawan, sering tidak memuaskan para nasabah seperti pelayanan yang lambat, kesulitan untuk melakukan transaksi. Sampel penelitian yang digunakan adalah non-probability sampling dengan sampel sebanyak 100 orang karyawan yang ada di PT.BCA. Teknik analisis data yang digunakan adalah uji validitas dan reliabilitas, uji asumsi klasik, dan hipotesis. Hasil penelitian menunjukkan bahwa terdapat pengaruh sistem dan prosedur pelatihan dan pengembangan karyawan terhadap kualitas kinerja karyawan pada PT. BCA dengan tingkat keyakinan $95 \%$.
\end{abstract}

Kata Kunci: Sistem, Prosedur, Pelatihan, Pengembangan, Kinerja

\section{PENDAHULUAN}

Perusahaan didirikan untuk tujuan memperoleh laba supaya dapat melakukan kegiatan usahanya dalam waktu yang tidak terbatas. Konsep yang menyatakan bahwa perusahaan diasumsikan melakukan kegiatan usahanya dalam waktu yang tidak terbatas dinamakan going concern concept. Untuk menerapkan konsep ini, maka manajemen harus dapat mengendalikan dan mengukur, apakah kegiatan perusahaan tersebut sesuai dengan tujuan perusahaan. Selain itu perusahaan juga harus dapat mengikuti perubahan dan perkembangan yang terjadi dalam dunia usaha.

Salah satu tujuan perusahaan adalah merekrut sumber daya manusia atau disingkat SDM yang cocok dengan tuntutan perusahaan yaitu "the right man in the right place". Seiring dengan perkembangan dunia usaha tersebut akibat adanya teknologi yang semakin maju, perusahaan juga perlu melengkapi kegiatan-kegiatannya dengan Sistem dan Prosedur. Sistem dan Prosedur ini perlu dievaluasi dari waktu ke waktu agar supaya kegiatan perusahaan yang ada selalu up to date dengan kemajuan teknologi dalam menganalisis Sistem dan prosedur apakah sudah berjalan sesuai dengan tujuannya. 
Ada bermacam-macam kegiatan yang mempengaruhi perusahaan dalam mencapai tujuannya, seperti: kegiatan SDM, Keuangan, Operasional, Pemasaran dan lain-lainnya. Karena banyaknya kegiatan-kegiatan perusahaan, maka penelitian ini akan dibatasi topik yang menyangkut pembahasan kegiatan mengenai Sistem dan Prosedur Pelatihan dan pengembangan.

Pengembangan karyawan yang relevan dengan perubahan lingkungan organisasi saat ini adalah pengembangan karyawan yang memungkinkan karyawan untuk menjadi lebih sadar dan tahu akan nilai, kekuatan, kelemahan, dan kepentingan mereka. Selain itu, karyawan dapat memperoleh informasi mengenai peluang kerja dalam perusahaan dan mampu mengidentifikasi tujuan pengembangan serta dapat menyusun rencana untuk mencapai tujuan karier.

Pengembangan karyawan dapat meningkatkan hasil kerja karyawan adalah target yang harus dicapai oleh suatu organisasi dalam rangka mencapai tujuan. Hasil kerja yang ingin dicapai tidak hanya menggambarkan titik akhir dari perencanaan kerja tetapi juga menunjukkan sistem pengorganisasian kerja, pengisian lowongan kerja, gaya kepemimpinan dan pengendalian karyawan yang kesemuanya ini merupakan faktor-faktor pendukung dari tercapainya hasil kerja yang diinginkan oleh suatu unit kerja.

Perusahaan melakukan aktivitas Pelatihan dan pengembangan, karena pelatihan dan pengembangan memegang peranan penting dalam menentukan kualitas kerja karyawan dalam sebuah perusahaan. Tanpa pelatihan dan pengembangan, perusahaan tidak bisa berbuat apa-apa. Pada PT. Bank Central Asia, Tbk. Terdapat masalah didalam sumber daya manusia yaitu Pelatihan dan pengembangan tidak dilakukan berdasarkan Sistem dan Prosedur, sehingga karyawan yang direkrut diberikan pelatihan tidak sesuai dengan kemampuannya untuk kebutuhan departemen yang memerlukannya. Pelatihan dan pengembangan tidak terlepas dari Sistem dan Prosedur, dimana terdapat masalah didalam Sistem dan Prosedur yang tidak pernah dievaluasi, data pelatihan dan pengembangan karyawan tidak sesuai dengan keterampilannya. Hal ini menarik perhatian untuk diteliti dengan tujuan agar permasalahan yang ada dapat diketahui penyebabnya sehingga dapat diberi saran permasalahannya.

Berdasarkan latar belakang masalah ini, maka perumusan masalah ini adalah: Apakah terdapat pengaruh sistem dan prosedur pelatihan terhadap kualitas kerja karyawan PT. Bank Central Asia?Apakah terdapat pengaruh sistem dan prosedur pengembangan terhadap kualitas kerja karyawan PT. Bank Central Asia?Apakah terdapat pengaruh sistem dan prosedur pelatihan dan pengembangan terhadap kualitas kerja karyawan PT. Bank Central Asia?

Tujuan dari penelitian ini adalah untuk mengetahui apakah ada pengaruh sistem dan prosedur pelatihan terhadap kualitas kinerja karyawan PT Bank Central Asia, untuk mengetahui apakah ada juga pengaruh sistem dan prosedur pengembangan terhadap kualitas kinerja karyawan PT Bank Central Asia, dan untuk mengetahui apakah ada pengaruh sistem dan prosedur pelatihan dan pengembangan terhadap kualitas kinerja karyawan PT Bank Central Asia.

\section{KAJIAN TEORI}

Menurut Flippo yang diterjemah kan oleh Moekijat (2003:4), pelatihan adalah "Proses membantu karyawan untuk memperoleh efektifitas dalam pekerjaan mereka yang sekarang atau yang akan datang melalui pengembangan kebiasaan pikiran dan tindakan, 
kecakapan, pengetahuan, dan sikap".Dessler (2007:297) "Pengembangan adalah usaha untuk meningkatkan prestasi manajemen dan menanamkan pengetahuan, perubahan, perilaku / peningkatan keterampilan".

Bitner dan Zeithaml (dalam Riorini, 2004:22) menyatakan untuk dapat meningkatkan performance quality (kualitas kerja) ada beberapa cara yang dapat dilakukan oleh perusahaan yaitu dengan memberikan pelatihan atau training, memberikan insentif atau bonus dan mengaplikasikan atau menerapkan teknologi yang dapat membantu meningkatkan efisiensi dan efektifitas kerja.

Mathis (2002: 5) mengemukakan bahwa "Pelatihan adalah suatu proses dimana orang-orang mencapai kemampuan tertentu untuk membantu mencapai tujuan organisasi. Oleh karena itu, proses ini terikat dengan berbagai tujuan organisasi, pelatihan dapat dipandang secara sempit dan luas “.

Oemar Humalik (2001:10) "Pelatihan merupakan suatu fungsi Manajemen yang perlu dilaksanakan terus-menerus dalam rangka pembinaan ketenagaan dalam organisasi. Secara spesifik, proses latihan itu merupakan tindakan (upaya) yang dilaksanakan secara berkesinambungan, bertahap dan terpadu. Tiap proses pelatihan harus terarah untuk mencapai tujuan tertentu terkait dengan upaya pencapaian tujuan organisasi".

Hal ini dipertegas oleh Veithzal Rivai (2004: 227) "Pelatihan adalah proses secara sistematis mengubah tingkah laku karyawan untuk mencapai tujuan organisasi. Pelatihan berkaitan dengan keahlian dan kemampuan karyawan untuk melaksanakan pekerjaan saat ini. Pelatihan memiliki orientasi saat ini dan membantu pegawai untuk mencapai keahlian dan kemampuan tertentu agar berhasil dalam melaksanakan pekerjaannya".

Amstrong (2000: 198) mengemukan pendapatnya bahwa "Pelatihan adalah konsep terencana yang terintegrasi, yang cermat, yang dirancang untuk menghasilkan pemahaman yang diperlukan untuk meningkatkan kinerja pekerjaan ".

Pengertian pelatihan menurut Ambar T. Sulistiyani dan Rosidah (2003: 175) bahwa "Pelatihan adalah proses sistematis pengubahan perilaku para karyawan dalam suatu arah guna meningkatkan tujuan-tujuan organisasional".

Dari kajian beberapa pendapat para ahli diatas dapat penulis simpulkan bahwa pelatihan yang digunakan PT Bank Central Asia adalah suatu proses pendidikan jangka pendek untuk meningkatkan pengetahuan, keahlian dan keterampilan teknis customer service untuk melaksanakan tugas dan tanggungjawabnya, sehingga customer service dapat memberikan kontribusi yang berarti bagi PT Bank Central Asia, yaitu dalam rangka memenuhi tuntutan para manajer dan departemen dengan upaya pencapaian tujuan organisasi. Maka penulis simpulkan dari beberapa pendapat para ahli bahwa pelatihan yang diterapkan PT Bank Central Asia merupakan pemberian pengetahuan dan keterampilan kepada customer service, guna untuk meningkatkan kinerja customer service, dimana customer service dalam melakukan pekerjaan akan mengalami perubahan yang memuaskan dengan sedikit kesalahan sehingga kualitas pelayanan dapat dijalankan dengan baik dan tanggung jawab terhadap pekerjaannya.

Pengembangan adalah suatu proses terciptanya bahan belajar, kegiatan pembelajaran dan penyampaiannya terhadap sekelompok peserta pelatihan yang terpilih mengikuti pelatihan. Dengan maksud tercapainya tujuan khusus pembelajaran yang dapat diukur.

Dessler (1997:297) "Pengembangan adalah usaha untuk meningkatkan prestasi manajemen dan menanamkan pengetahuan, perubahan, perilaku / peningkatan keterampilan".Veithzal (2005:227) "Pengembangan adalah suatu proses bagaimana 
manajemen mendapatkan pengalaman, keahlian, dan sikap untuk menjadi sukses sebagai pemimpin dalam organisasi mereka".

Pelatihan dan pengembangan dapat memperkuat tingkat komitmen para karyawan pada organisasi dan meningkatkan persepsi mereka bahwa organisasi merupakan tempat yang baik untuk bekerja.Para ahli mengakui bahwa pelatihan dan pengembangan dapat menguntungkan masyarakat dengan memungkinkan individu menjadi anggota organisasi yang produktif dan mendukung.Pelatihan diberikan atas dasar kebutuhan untuk mempelajari definisi keahlian dan juga untuk melengkapi para karyawan dengan keahlian spesifik pekerjaan di kemudian hari.

Singarimbun (1989: 51) pengaruh adalah hubungan yang paling dasar antara dua variabel yakni: variabel pengaruh (independen variabel) dengan variabel terpengaruh (dependen variabel) istilah pengaruh biasanya juga dikaitkan dengan analisis hubungan kausal (hubungan sebab dan akibat).

Steven diterjemahkan oleh Zaki (1993:4), sistem adalah : "Suatu kesatuan (entity) yang terdiri dari bagian-bagian (disebut sub sistem) yang saling berkaitan dengan tujuan untuk mencapai tujuan-tujuan tertentu." "Pada dasarnya sistem adalah sekelompok elemen yang erat berhubungan satu dengan lainnya, yang berfungsi bersama-sama untuk mencapai tujuan tertentu". (Mulyadi, 1989:5). McLeod diterjemahkan oleh Hendra (1995:13)," Sistem adalah sekelompok elemen-elemen yang terintegrasi dengan maksud yang sama untuk mencapai tujuan yang sama".

Mulyadi (2001:5), "prosedur adalah klerikal, biasanya melibatkan beberapa orang dalam suatu departemen atau lebih, yang dibuat untuk menjamin penanganan secara seragam kegiatan perusahaan yang terjadi berulang-ulang."Wijana (2002: 27), menyatakan bahwa prosedur adalah rangkaian langkah atau kegiatan yang saling berhubungan satu sama lain secara esensial yang diikuti pendekatan fungsional.

Baridwan (1993:3) menyatakan "Prosedur adalah suatu urutan-urutan pekerjaan kerani (clerical), biasanya melibatkan beberapa orang dalam satu bagian atau lebih, disusun untuk menjamin adanya perlakuan yang seragam terhadap transaksi-transaksi perusahaan yang sedang terjadi”. Dari definisi di atas disimpulkan bahwa prosedur adalah sebuah perintah yang dapat digunakan untuk membagi beberapa kejadian dalam suatu kumpulan perintah yang lebih kecil dengan berbagai kelengkapan di dalamnya baik itu pengecekan kondisi, fungsi matematika maupun fungsi string. Dengan menggunakan prosedur atau fungsi dapat menghemat banyak ruang dalam dan menghindari pengetikan kode yang berulang-ulang.

\section{Kerangka Pemikiran}

Dari uraian di atas dapat digambarkan kerangka pemikiran sebagai berikut:

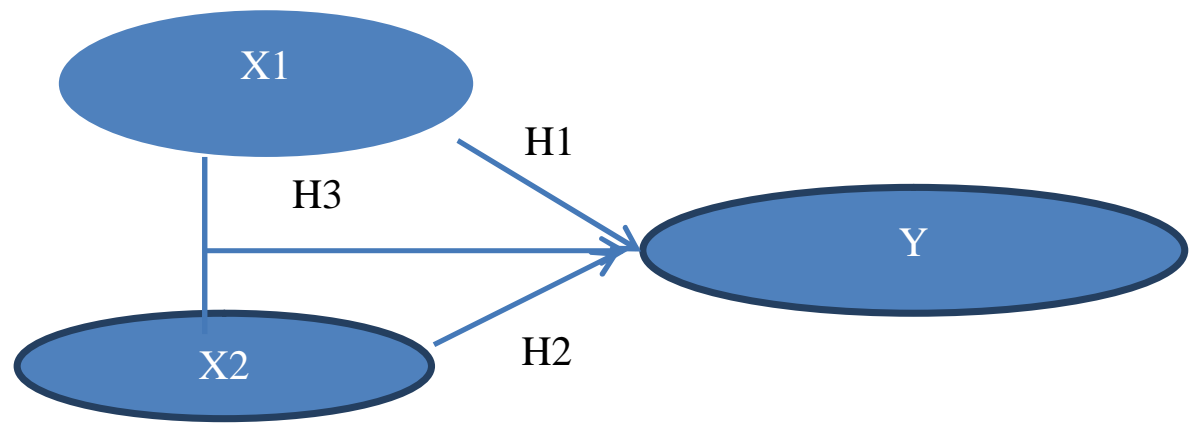


Keterangan: $\mathrm{X} 1$ = Sistem dan prosedur pelatihan karyawan; X2 = Sistem dan prosedur pengembangan karyawan; $\mathrm{Y}=$ Kualitas kerja karyawan

Hipotesis. Arikunto (2002: 64) hipotesis adalah suatu jawaban yang bersifat sementara terhadap permasalahan penelitian sampai terbukti melalui data yang didapatkan dari hasil penelitian. Hipotesis dalam penelitian ini adalah:

$\mathrm{H}_{1}$ : terdapat pengaruh sistem dan prosedur pelatihan karyawan terhadap kualitas kerja karyawanpada PT Bank Central Asia

$\mathrm{H}_{2}$ : terdapat pengaruh sistem dan prosedur pengembangan karyawan terhadap kualitas kerja karyawan pada PT Bank Central Asia

$\mathrm{H}_{3}$ : terdapat pengaruh sistem dan prosedur pelatihan dan pengembangan karyawan terhadap kualitas kerja karyawan pada PT Bank Central Asia

\section{METODE}

Lokasi yang akan dijadikan sampel penelitian adalah PT Bank Central Asia Tbk di Jakarta Pusat, dengan mengambil sampel sebanyak 100 orang. Desain penelitian bersifat deskriptif (Descriptive Research) bermaksud membuat pemeriaan (penyadaran) secara sistematis, faktual, dengan akurat mengenai fakta-fakta dan sifat-sifat populasi tertentu (Husaini, 2003: 4).

Jenis penelitian ini merupakan jenis penelitian kuantitatif. "Data kuantitatif adalah data yang berbentuk angka, atau data kualitatif yang diangkakan (skoring)". (Sugiono, 2007: 23)Penelitian ini dimaksudkan untuk mengetahui adanya pengaruh antara variabel dependen (variabel terikat) dan variabel independen (variabel bebas) sedangkan rumus yang digunakan adalah: $\mathrm{Y}=\mathrm{a}+\beta \mathrm{X}_{1}+\beta \mathrm{X}_{2}$

Untuk memperoleh data dan informasi yang diperlukan, maka pengumpulan data tersebut dilakukan dengan kuesioner yaitu teknik pengumpulan data melalui pertanyaan yang diajukan kepada para karyawan PT Bank Central Asia Tbk di Jakarta, pertanyaan dapat juga menangani cara karyawan menilai sesuatu tentang perilakunya sendiri dalam hubungannya dengan orang lain atau lingkungan. Tujuan pokok pembuatan kuesioner adalah untuk memperoleh informasi yang relevan dengan tujuan penelitian. Dalam hal ini kuesionerdimaksudkan sebagai suatu daftar pertanyaan tertutup yang memberikan pertanyaan dengan alternatif jawaban yang telah tersedia.

Teknik Analisis Data. Ada tiga asumsi yang perlu diuji, yaitu sebagai berikut: (Ghozali, 2006: 91)Multikolinieritas terjadi bila antar dua atau lebih 232ariable independen memiliki Korelasi yang signifikan atau sempurna atau mendekati 1 atau -1 . Untuk mendeteksi ada atau tidaknya multikolinieritas dalam model persamaan penelitian ini, penulis melihat dari besaran VIF (Variance Inflation Factor), jika VIF $>5$, berarti terdapat multikolinieritas (Singgih, 2000:206).

Heteroskedastisitas terjadi apabila untuk setiap nilai variabel independen terjadi beberapa skor variabel dependen dengan variansi berbeda. Uji normalitas bertujuan untuk menguji apakah dalam suatu model regresi, variable dependen, variable independen atau keduanya terdistribusi normal atau tidak. Model regresi yang baik seharusnya distribusi datanya normal atau mendekati normal.Jika data menyebar jauh dari garis diagonal dan atau tidak mengikuti arah garis diagonal, maka model regresi tersebut tidak memenuhi asumsi normalitas (Singgih, 2000:214). 
Metode analisis data yang digunakan adalah analisis regresi berganda. Persamaan regresi berganda mengandung makna bahwa dalam suatu persamaan regresi terdapat satu variabel dependen dan lebih dan satu variabel independen (Sugiyono, 2005). Variabel dependen dilambangkan dengan $\mathrm{Y}$, dan variabel independen dilambangkan dengan $\mathrm{X}$. Secara umum model regresi berganda dirumuskan sebagai berikut: $Y=\mathbf{a}+\boldsymbol{b}_{1} \boldsymbol{X}_{1}+\boldsymbol{b}_{2} \boldsymbol{X}_{2}$.

\section{Pembahasan}

\section{Flow Chart I}

Sistem dan Prosedur dan Pelatihan Karyawan di PT Bank Central Asia.

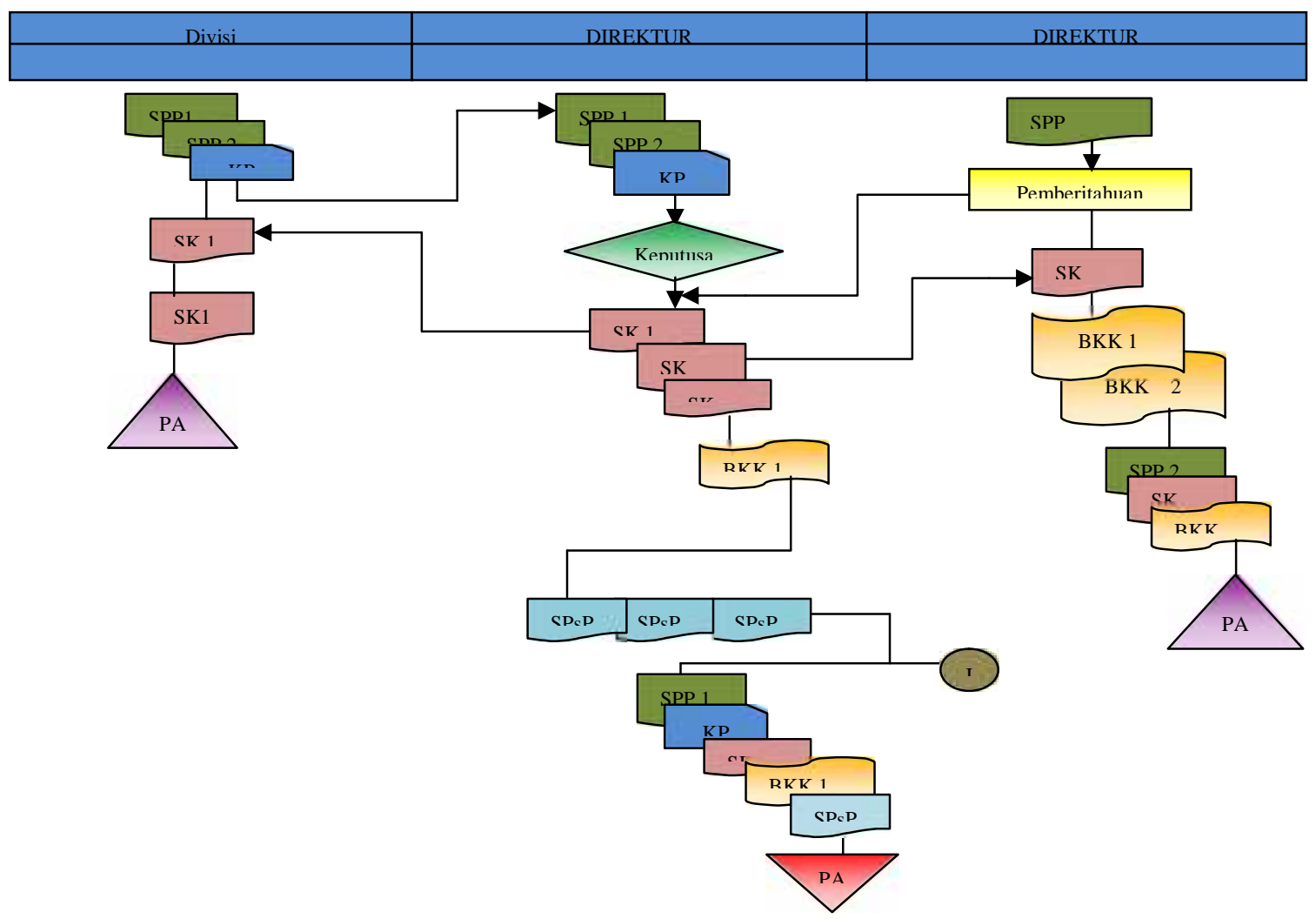

Keterangan: Formulir Surat Permohonan Pelatihan (SPP); Formulir Kartu Pegawai (KP); Formulir Pemberitahuan Anggaran (PA); Formulir Surat Keputusan (SK); Formulir Bukti Kas Keluar (BKK); Formulir Surat Persiapan Pelatihan (SPsP).

User Divisi mengisi Surat Permohonan Pelatihan (SPP) dengan menyertai salinan Kartu Pegawai (KP) kepada Direktur. Surat Permohonan Pelatihan (SPP) dibuat 2 rangkap, SPP 1 diserahkan kepada Direkturuntuk pertimbangan keputusan apakah akan diselengarakannya pelatihan atau tidak.SPP 2 diserahkan kepada Wakil Dirketuruntuk menyiapkan anggaran pelatihan.Kartu Pegawai (KP) hanya dibuat 1 rangkap dan diserahkan kepada Direktur.

Direktur menerima SPP 1 dan KP, serta SPP 2 sebelum diserahkan kepada Wakil Direktur, untuk memutuskan akan disetujui atau tidak. Jika disetujui maka proses akan dilanjutkan, Direktur memproses SPP 1 dan salinan KP, kemudian SPP 2 baru diserahkan pada Wakil Direktur untuk diproses. Wakil Direkturakan memberitahukan besarnya anggaran yang akan dikeluarkan untuk mengadakan Pelatihan dan Pengembangan kepada 
Direktur. Selanjutnya Direktur memberikan keputusan atas persetujuan di selenggarakan Pelatihan dan Pengembangan dengan membuat Surat Keputusan (SK). Surat Keputusan (SK) dibuat 3 rangkap, SK 1 diserahkan kepada Departemen yang membutuhkan, SK 2 diserahkan kepada Wakil Direktur, dan SK 3 diserahkan kepada Direktur.

Wakil Direktur menyetujui anggaran yang dibutuhkan untuk pelatihan kepada Direktur, disertai dengan Bukti Kas Keluar (BKK). Bukti Kas Keluar (BKK) dibuat 2 rangkap, BKK 1 diserahkan kepada Direktur, BKK 2 diserahkan kepada Wakil Direktur. Wakil Direktur mengarsipkan SPP 2, SK 2 dan BKK 2 untuk disimpan dalam arsip permanen.

Departemen yang membutuhkan menerima SK 1, kemudian mengarsipkan SK 1 untuk disimpan dalam arsip permanen.Direktur menerima dana tunai serta BKK 1 untuk membuktikan bahwa anggaran telah diserahkan. Kemudian Direkturmembuat Surat Persiapan Pelatihan (SPsP).Surat Persiapan Pelatihan (SPsP) dibuat 3 rangkap, SPsP 1 diserahkan kepada Divisi Pelatihan dan Pengembangan, SPsP 2 diserahkan kepada Wakil Direktur, SPsP 3 diserahkan kepada Direktur. Kemudian Direkturmenyiapkan SPP 1, KP, SK 3, BKK 1, dan SPsP 3 untuk disimpan dalam arsip sementara.

Sistem Dan Prosedur Persiapan Pelatihan Karyawan Customer Service PT Bank Central Asia(FC II). Unit organisasi yang terlibat dalam Sistem dan Prosedur Persiapan Pelatihan Karyawan Customer Service PT Bank Central Asia Tbk di Jakarta Barat.

Sistem dan Prosedur Persiapan Pelatihan Karyawan Customer Service melibatkan beberapa Departemen/bagian dalam perusahaan dengan maksud agar Sistem dan Prosedur Persiapan Pelatihan beserta Flowchartnyadapat membantu perusahaan betul-betul serius dalam melaksanakan pelatihan Karyawan secara Profesional.Unit organisasi yang terlibat dalam Sistem dan Prosedur Persiapan Pelatihan Karyawan yaitu: Direktur, Divisi Pelatihan dan Pengembangan, User Divisi/ Kantor Wilayah, Kantor Cabang Utama, Kantor Cabang Pembantu, dan Wakil Direktur.

Formulir yang digunakan dalam Sistem dan Prosedur Persiapan Pelatihan Karyawan customer service PT Bank Central Asia Tbk di Jakarta Pusat, yaitu: (1) Formulir Surat Persiapan Pelatihan (SPsP); (2) Formulir Surat Pemberitahuan Jadwal Pelatihan (SPJP); (3) Formulir Surat Keputusan KW, KCU, KCP (SKM); (4) Formulir Surat Keputusan KW, KCU, KCP (SKT).

Pada Flow chart 2. Keterangan: Formulir Surat Persiapan Pelatihan (SPsP); Formulir Surat Pemberitahuan Jadwal Pelatihan (SPJP); Formulir Surat Keputusan KW, KCU, KCP (SKM); Formulir Surat Keputusan KW, KCU, KCP (SKT)

Divisi Pelatihan dan Pengembanganmenerima SPsP 1 dan Direkturmenerima SPsP 2. Wakil Direkturmembuat Surat Pemberitahuan Jadwal Pelatihan (SPJP) untuk mengetahui kegiatan Pelatihan yang akan dilaksanakan.SPJP dibuat 3 rangkap, rangkap 1 diserahkan kepada Wakil Direktur, rangkap 2 diserahkan kepada Divisi Pelatihan dan Pengembangan, dan rangkap 3 diserahkan kepada User Divisi/ $K W, K C U, K C P$.

Divisi Pelatihan dan Pengembangan menerima SPJP 2, lalu membuat Surat keputusan. Surat keputusan untuk KW, KCU, KCP, gunanya untuk memutuskan menggunakan Mentor dari dalam perisajaan (Divisi Pelatihan dan Pengembangan) atau dari luar perusajaan (eksternal), serta untuk pemberian honor pada saat selesai memberikan pelatihan. KW, KCU, KCP dibuat 2 rangkap, KW, KCU, KCP 1 untuk KW, KCU, KCP dan SKM 2 untuk Divisi Pelatihan dan Pengembangan. 


\section{Flow Chart II}

Sistem dan Prosedur Persiapan Pelatihan KaryawanCustomer ServicePT Bank Central Asia

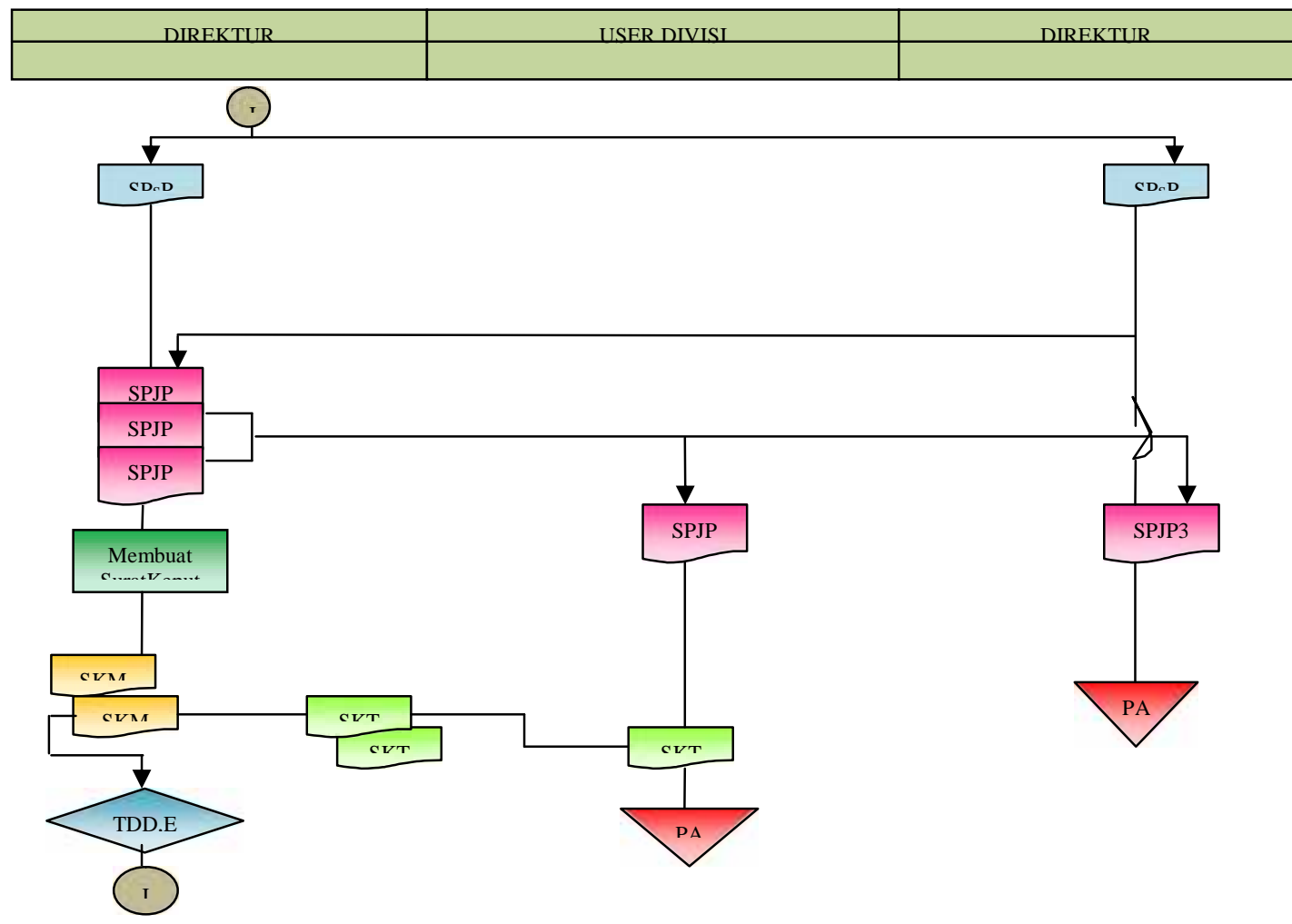

Surat keputusan untuk KW, KCU, KCP, gunanya untuk pemberitahuan bahwa mereka dipanggil sebagai peserta pelatihan serta untuk pemberian honor peserta selama pelatihan berlangsung. Surat keputusan KW, KCU, KCP dibuat 2 rangkap, SKT 1 untuk User Divisi/KW, KCU, KCP dan SKT 2 untuk Divisi Pelatihan dan Pengembangan.

User Divisi/KW, KCU, KCPmenerima SPJP 2 dan SKT 1, yang kemudian disimpan dalam arsip sementara.

Direktur menerima SPJP 3, kemudian menyimpan SPsP 2 dan SPJP 3 dalam arsip sementara.

Sistem Dan Prosedur Persiapan Pelatihan Karyawan pada PT Bank Central Asia (FC III). Unit organisasi yang terlibat dalam Sistem dan Prosedur Persiapan Pelatihan Karyawanpada PT Bank Central Asia Tbk Di Jakarta Barat.Sistem dan Prosedur Persiapan Pelatihan Karyawan melibatkan beberapa Departemen / bagian dalam perusahaan dengan maksud agar Sistem dan Prosedur Persiapan Pelatihan beserta Flowchartnyadapat membantu perusahaan betul - betul serius dalam melaksanakan pelatihan Karyawan secara Profesional.Unit organisasi yang terlibat dalam Sistem dan Prosedur Persiapan Pelatihan Karyawan yaitu: Wakil Direktur,Divisi Pelatihan dan Pengembangan,User Divisi/ $K W, K C U, K C P$, dan Direktur.

Formulir yang digunakan dalam Sistem dan Prosedur Persiapan Pelatihan Karyawan customer service pada PT Bank Central Asia Tbk di Jakarta Barat, yaitu: (1) Formulir Surat Pemberitahuan Pelaksanaan Pelatihan (SPPP); (2) Formulir Surat Persiapan 
Pelatihan (SPsP); (3) Formulir Surat Pemberitahuan Jadwal Pelatihan (SPJP); (4) Formulir Surat Keputusan KW, KCU, KCP (SKT).

Flow Chart III

Sistem dan Prosedur Persiapan Pelatihan Karyawanpada PT Bank Central Asia

\begin{tabular}{|c|c|c|}
\hline DIREKTUR & USER DIVISI & DIREKTUR \\
\hline DIVISI PELATIHAN DAN & KW. KCU. KCP & WAKIL DIREKTUR \\
\hline
\end{tabular}

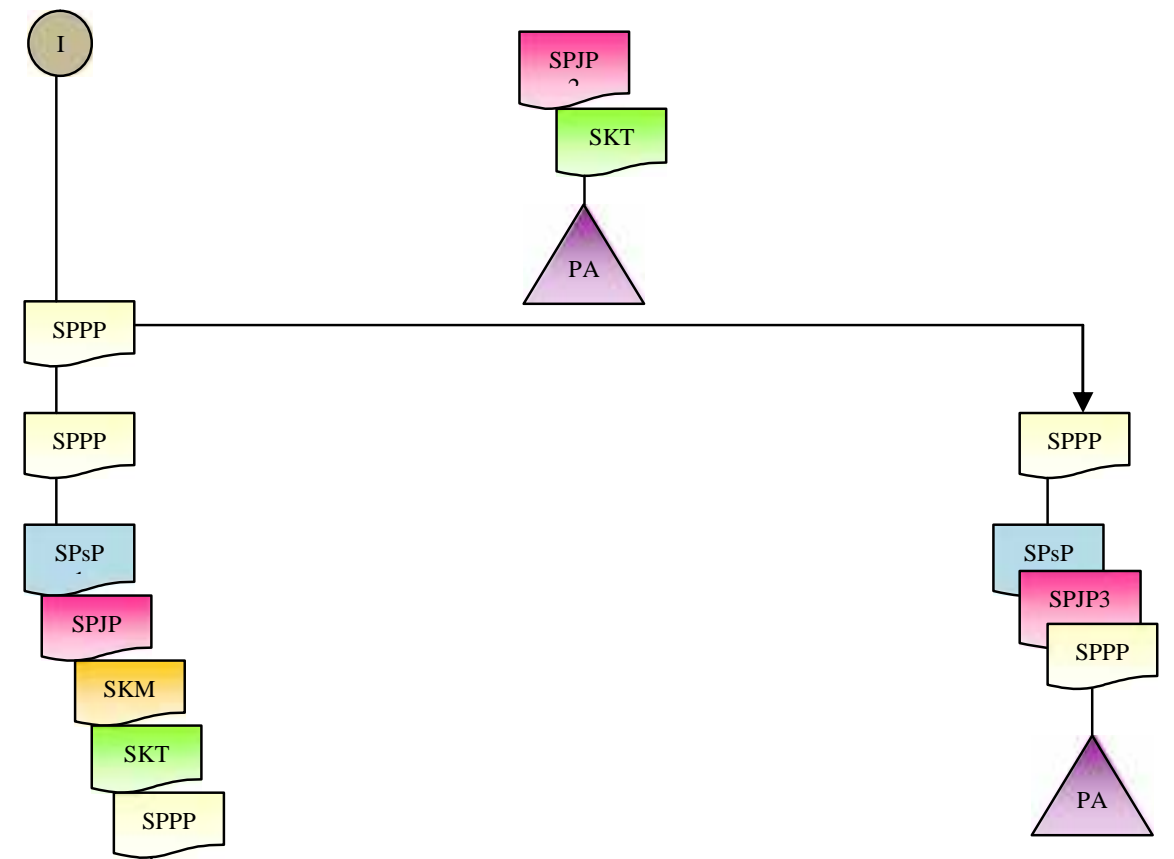

Keterangan: Formulir Surat Pemberitahuan Pelaksanaan Pelatihan (SPPP); Formulir Surat Persiapan Pelatihan (SPsP); Formulir Surat Pemberitahuan Jadwal Pelatihan (SPJP); Formulir Surat Keputusan KW, KCU, KCP (SKT)

Divisi Pelatihan dan Pengembanganmembuat Surat Pemberitahuan Pelaksanaan Pelatihan (SPPP). SPPP di buat 2 rangkap, SPPP 1 untuk Direktur, dan SPPP 2 untuk Divisi Pelatihan dan Pengembangan.Divisi Pelatihan dan Pengembangan menerima SPsP 1, kemudian menyimpan SPsP 1, SPJP 1, SKM 2 dan SPPP 2, dan SKT 2 dalam arsip permanen.

User Divisi/ $K W, K C U, K C P$ menerima SPJP 2 dan SKT 1, yang kemudian disimpan dalam arsip permanen.Direktur menerima SPPP 1, kemudian menyimpan SPsP 2, SPJP 3, dan SPPP 1 dalam arsip permanen.

Sistem Dan Prosedur Persiapan Pelatihan Karyawan pada PT Bank Central Asia(FC IV). Unit organisasi yang terlibat dalam Sistem dan Prosedur Persiapan Pelatihan Karyawanpada PT Bank Central Asia Tbk di Jakarta Barat.

Sistem dan Prosedur Persiapan Pelatihan Karyawan melibatkan beberapa Departemen / bagian dalam perusahaan dengan maksud agar Sistem dan Prosedur Persiapan Pelatihan 
beserta Flowchartnyadapat membantu perusahaan betul-betul serius dalam melaksanakan pelatihan Karyawan secara Profesional.Unit organisasi yang terlibat dalam Analisis Sistem dan Prosedur Persiapan Pelatihan Karyawan yaitu: Wakil Direktur, Divisi Pelatihan dan Pengembangan, dan User Divisi/ $K W, K C U, K C P$.

Formulir yang digunakan dalam Sistem dan Prosedur Persiapan Pelatihan Karyawan pada PT Bank Central Asia Tbk di Jakarta Barat, yaitu: (1) Formulir Kartu Pengenal Peserta (KPP); (2) Formulir Pra - Test (F Pr T); (3) Formulir Post - Test (F Po T); (4) Formulir Kurikulum Pelatihan (KrP); (5) Formulir Daftar Hadir Peserta (DHP); (6) Formulir Program Pelatihan (PP); (7) Formulir Sertifikat (F S); (8) Formulir Surat Ijin Praktek Kerja Lapangan (SIPKL); (9) Formulir Kartu Praktek Kerja Lapangan (K - PKL); (10) Formulir Surat Pemberitahuan Jadwal Pelatihan (SPJP); (11) Formulir Surat Keputusan KW, KCU, KCP (SKT)

Flow Chart IV

Sistem dan Prosedur Persiapan Pelatihan Karyawanpada PT Bank Central Asia

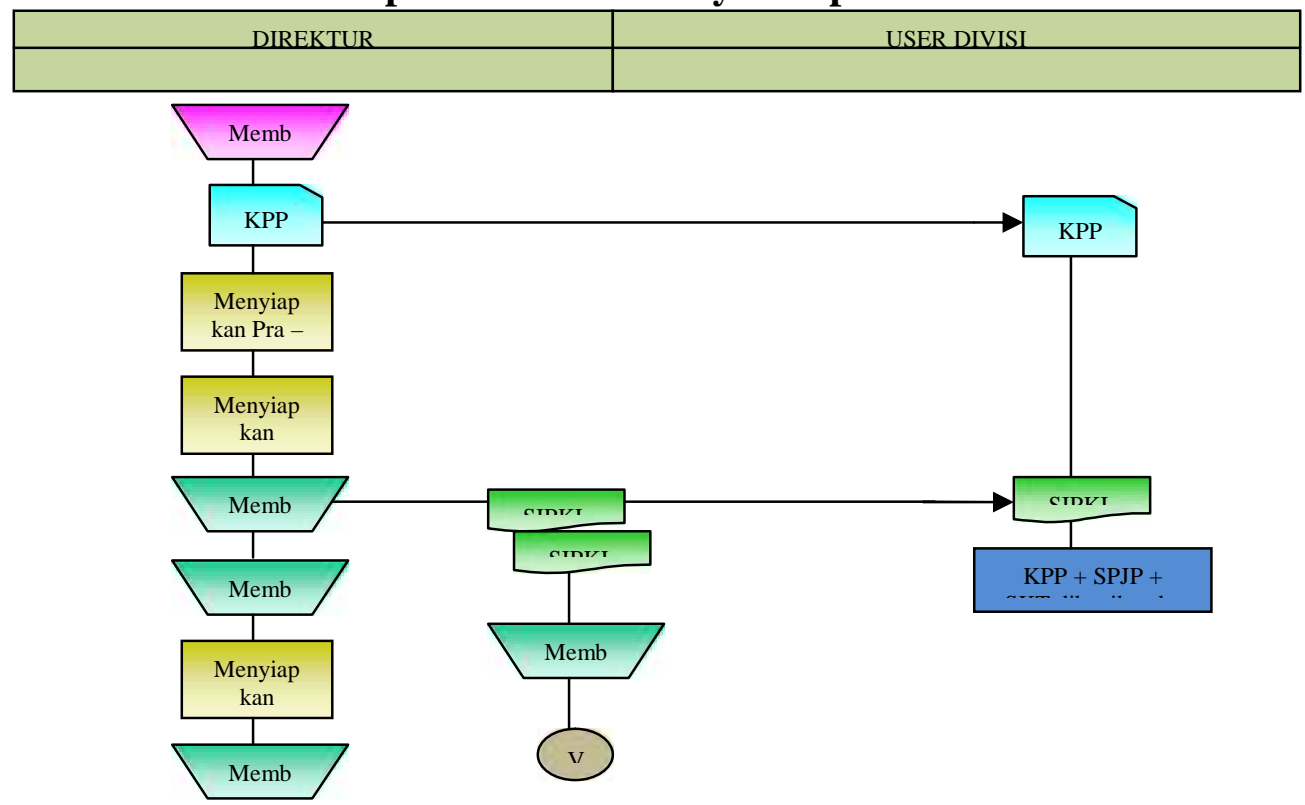

Keterangan : Formulir Kartu Pengenal Peserta (KPP); Formulir Pra - Test (F Pr T); Formulir Post - Test (F Po T); Formulir Kurikulum Pelatihan (KrP); Formulir Daftar Hadir Peserta (DHP); Formulir Program Pelatihan (PP); Formulir Sertifikat (F S); Formulir Surat Ijin Praktek Kerja Lapangan (SIPKL); Formulir Kartu Praktek Kerja Lapangan (K - PKL); Formulir Surat Pemberitahuan Jadwal Pelatihan (SPJP); Formulir Surat Keputusan KW, KCU, KCP (SKT)

Divisi Pelatihan dan Pengembanganmembuat Kartu pengenal Peserta (KPP) yang akan diserahkan kepada User Divisi / KW, KCU, KCP.Kemudian menyiapkan Kurikulum Pelatihan $(\mathrm{KrP})$, membuat Daftar Hadir Peserta (DHP), menyiapkan program Pelatihan (PP), serta membuat Setifikat sebagai tanda telah menjalani Program Pelatihan.

Divisi Pelatihan dan Pengembangan membuat Surat Ijin Praktek Kerja Lapangan (SIPKL). Surat Ijin Praktek Kerja Lapangan (SIPKL) dibuat dalam 2 rangkap, SPIKL 1 untuk KW, KCU, KCP, dan SIPKL 2 untuk Divisi Pelatihan dan Pengembangan. Serta membuat Kartu Praktek Kerja Lapangan (K-PKL) yang akan digunakan KW, KCU, KCP untuk menjalankan pelatihan selama On The Job Training. 
User Divisi / KW, KCU, KCP menerima Kartu Pengenal Peserta (KPP), kemudian KPP, SPJP, SKT 1, serta SIPKL 1 dibagikan ke tiap KW, KCU, KCP, gunanya untuk sebagai bukti agar KW, KCU, KCP dapat mengikuti pelatihan.

\section{Sistem Dan Prosedur Pelaksanaan Pelatihan Karyawan pada PT Bank Central Asia} (FC V). Unit organisasi yang terlibat dalam Analisis Sistem dan Prosedur Pelaksanaan Pelatihan Karyawanpada PT Bank Central Asia Tbk di Jakarta Barat.Sistem dan Prosedur Pelaksanaan Pelatihan Karyawan melibatkan beberapa unit organisasi yaitu: Wakil Direktur, Divisi Pelatihan dan Pengembangan, dan User Divisi/ KW, KCU, KCP.

Formulir yang digunakan dalam Analisis Sistem dan Prosedur Pelaksanaan Pelatihan Karyawan pada PT Bank Central Asia Tbk di Jakarta Pusat, yaitu: (1) Formulir Daftar Hadir Peserta (DHP); (2) Formulir Pra - Test (F Pr T); Formulir Kurikulum Pelatihan $(\mathrm{KrP})$; Formulir Program Pelatihan (PP); Formulir Kartu Praktek Kerja Lapangan (K PKL); Formulir Kartu Pengenal Peserta (KPP); Formulir Surat Keputusan KW, KCU, $\mathrm{KCP}(\mathrm{SKT})$.

\section{Flow Chart $V$}

\section{Sistem dan Prosedur Pelaksanaan Pelatihan Karyawan pada PT Bank Central Asia}

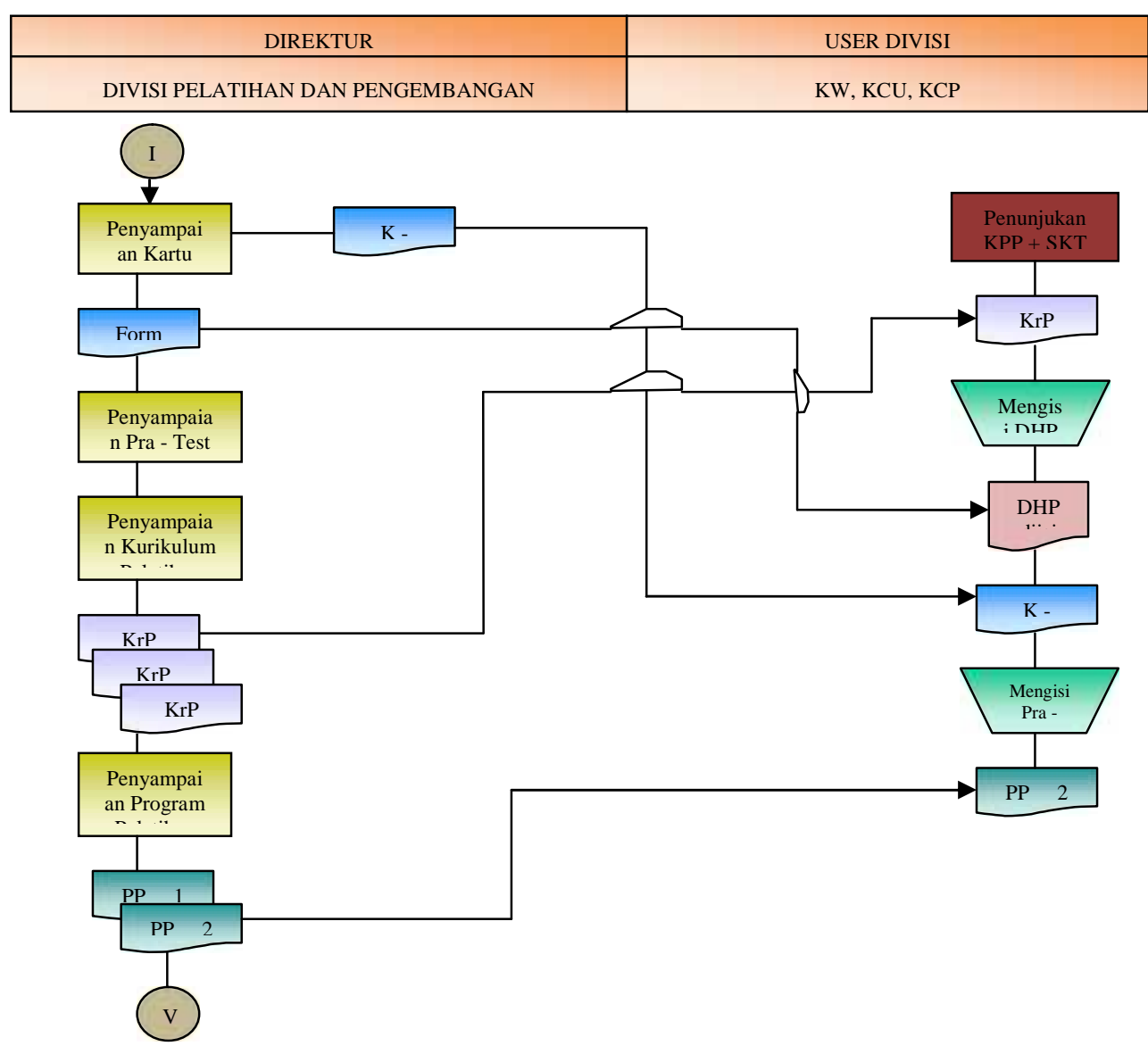

Keterangan : Formulir Daftar Hadir Peserta (DHP); Formulir Pra - Test (F Pr T); Formulir Kurikulum Pelatihan (KrP); Formulir Program Pelatihan (PP); Formulir Kartu Praktek Kerja Lapangan (K - PKL); Formulir Kartu Pengenal Peserta (KPP); Formulir Surat Keputusan KW, KCU, KCP (SKT). 
Divisi Pelatihan dan Pengembangan membuat Daftar Hadir Peserta (DHP) dan menyerahkan pada $K W, K C U, K C P$ untuk diisi. Kemudian menyampaikan Pra-test pada $K W, K C U, \quad K C P$ untuk diisi.Menyampikan Kurikulum Pelatihan (KrP).Kurikulum Pelatihan dibuat 3 rangkap, Krp 1 untuk User Divisil $K W, K C U, K C P$, Krp 2 untuk Mentor, dan Krp 3 utuk Divisi Pelatihan dan Pengembangan.

Menyampaikan Program Pelatihan (PP),dibuat menjadi 2 rangkap.PP 1 untuk User Divisi/ $K W, K C U, K C P$ dan PP 2 untuk Divisi Pelatihan dan Pengembangan.

$K W, K C U, K C P$ harus menunjukkan Kartu Pengenal Peserta (KPP) dan Surat Keputusan KW, KCU, KCP (SKT 1) sebelum mengisi Daftar Hadir Peserta (DHP), gunanya untuk membuktikan bahwa bener mereka adalah $K W, K C U, K C P$ / peserta pelatihan yang diputuskan untuk mengikuti pelatihan oleh Divisi Pelatihan dan Pengembangan. Setelah Daftar Hadir Peserta (DHP) diisi, $K W, K C U, K C P$ mendapatkan Kartu Praktek Kerja Lapangan (K- PKL). Kemudian mengisi Pra - test gunanya untuk mengetahui level pengetahuan yang $K W, K C U, K C P$ miliki sebelum pelatihan dilaksanakan. $K W, K C U, K C P$ juga menerima Program Pelatihan (PP 2) dari Divisi Pelatihan dan Pengembangan.

Sistem Dan Prosedur Pelatihan Dan Pengembangan Karyawan pada PT Bank Central Asia (FC VI). Unit organisasi yang terlibat dalam Sistem dan Prosedur Pelatihan dan Pengembangan Karyawanpada PT Bank Central Asia Tbk di Jakarta Barat.

Sistem dan Prosedur Pelatihan dan Pengembangan Karyawan melibatkan beberapa unit organisasi yaitu: Wakil Direktur, Divisi Pelatihan dan Pengembangan, dan User Divisi/ KW, KCU, KCP.

Formulir yang digunakan dalam Analisis Sistem dan Prosedur Pelatihan dan Pengembangan Karyawan, adalah: Formulir Pra - Test (F Pr T); Formulir Post - Test (F Po T); Formulir Penilaian Akhir Penyelenggaraan Pelatihan (F PAPP); Formulir Sertifikat (F S)

Pada Flow Chart VI. Keterangan: Formulir Pra - Test (F Pr T); Formulir Post - Test (F Po T); Formulir Penilaian Akhir Penyelenggaraan Pelatihan (F PAPP); Formulir Sertifikat (F S)

Divisi Pelatihan dan Pengembangan mengevaluasi test awal (Pra - test) yang diisi oleh KW, KCU, KCP untuk mengetahui level pengetauan yang mereka miliki sebelum pelatihan dilaksanakan.Setelah pelaksanaan pelatihan selesai, selanjutnya penyampaian evaluasi akhir (Post - test) yang diberikan pada KW, KCU, KCP untuk diisi.Setelah Post -test diisi dikembalikan ke Divisi Pelatihan dan Pengembangan untuk dievaluasi.Gunanya untuk mengetahui penyerapan $K W, K C U, K C P$ / peserta atas materi pelatihan yang telah diberikan.Kemudian perbandingan hasil Pra - test dengan Post - test diberikan kepada User Divisi.Selanjutnya membuat Penilaian Akhir Penyelenggaraan Pelatihan dengan menerima evaluasi pelaksanaan pelatihan menurut $K W, K C U, K C P$, dimana yang mengetahui hanyalah Divisi Pelatihan dan Pengembangan.Kemudian Divisi Pelatihan dan Pengembangan membuat laporan Penyelenggaraan Pelatihan, bertujuan untuk mengumpulkan data yang akan dipergunakan untuk penyempurnaan penyelenggaraan Pelatihan di masa yang akan datang. 


\section{Flow Chart VI}

\section{Sistem dan Prosedur Pelatihan dan Pengembangan Karyawan pada PT Bank Central Asia Tbk Di Jakarta Pusat}

\begin{tabular}{|c|c|}
\hline DIREKTUR & USER DIVISI \\
\hline DIVISI PELATIHAN DAN PENGEMBANGAN & KW, KCU, KCP \\
\hline
\end{tabular}

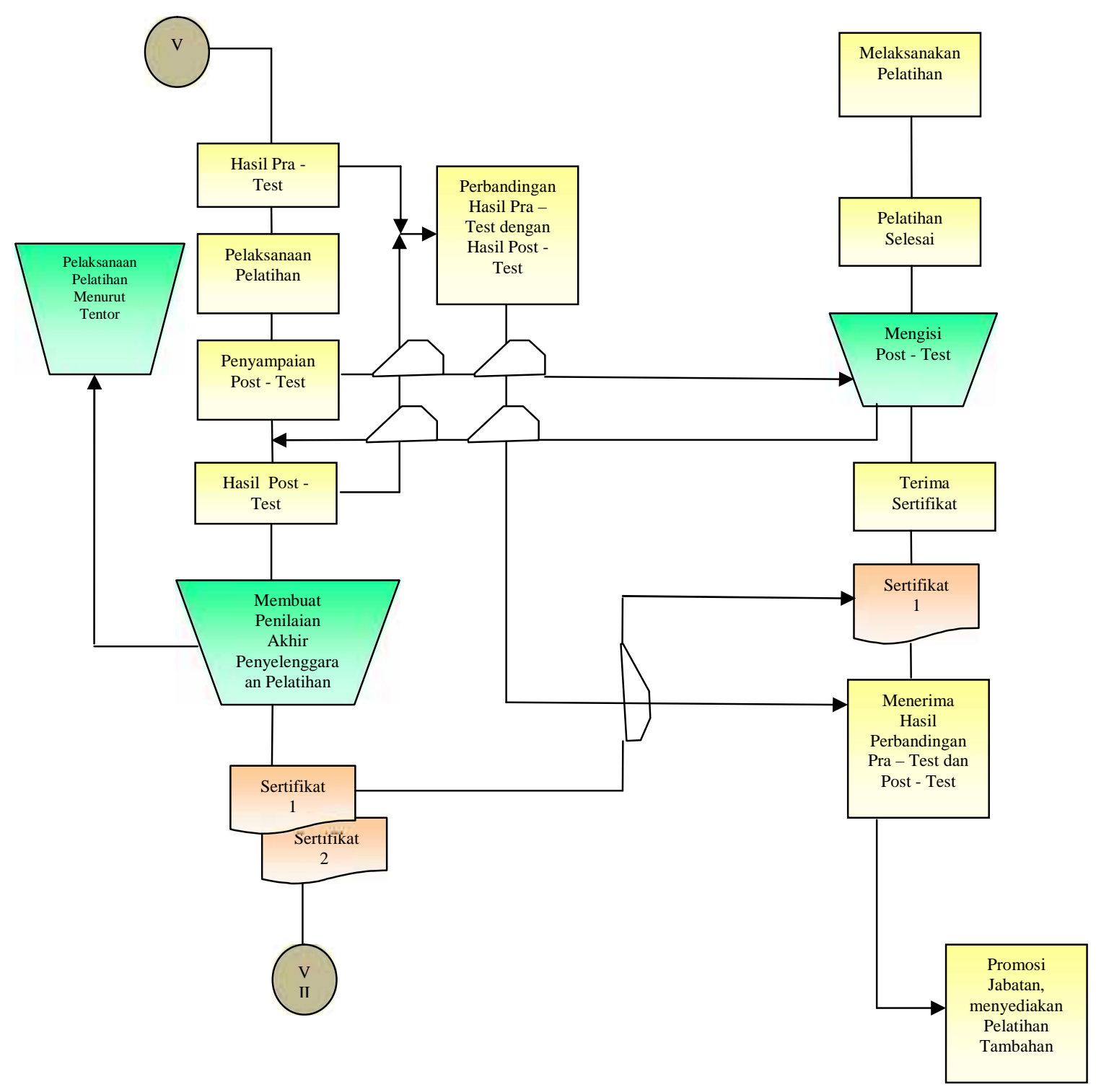

Setelah pelatihan selesai, $K W, K C U, K C P$ melaksanakan kembali evaluasi akhir (Post - test).Kemudian mereka juga meminta sertifikat yang dibuat dalam 2 rangkap : Sertifika 1 untuk $K W, K C U, K C P$, sebagai tanda bahwa mereka telah selesai mengikuti program pelatihan dan Sertifikat 2 untuk Divisi Pelatihan dan Pengembangan, sebagai bukti $\mathrm{KW}, \mathrm{KCU}, \mathrm{KCP} /$ peserta yang dilatih pernah mengikuti pelatihan di perusahaan.

User Divisi menerima hasil perbandingan antara Pra - test dengan Post -test dari Divisi Pelatihan dan Pengembangan, yang kemudian dibandingkan apakah saat sebelum 
pelatihan atau sesudah pelatihan terjadi peningkatan atau penurunan pada masing-masing $K W, K C U, K C P$ / peserta.Jika terjadi penurunan, maka disediakan pelatihan tambahan bagi $K W, K C U, K C P$.

\section{Sistem Dan Prosedur Pelatihan Dan Pengembangan Karyawan pada PT Bank Central Asia Tbk di Jakarta Pusat (FC VII)}

Unit organisasi yang terlibat dalam Sistem dan Prosedur Pelatihan dan Pengembangan Karyawanpada PT Bank Central Asia Tbk di Jakarta Barat.

Sistem dan Prosedur Pelatihan dan Pengembangan Karyawan melibatkan beberapa unit organisasi yaitu: Wakil Direktur, Divisi Pelatihan dan Pengembangan, User Divisi / KW, KCU, KCP, dan Direktur.

Formulir yang digunakan dalam Analisis Sistem dan Prosedur Pelatihan dan Pengembangan Karyawan, adalah: Formulir Laporan Penyelenggaraan Pelatihan (LPP); Formulir Program Pelatihan (PP); Formulir Kurikulum Pelatihan (KrP); Formulir Surat Ijin Praktek Kerja Lapangan (SIPKL)

Flow Chart VII

Analisis Sistem dan Prosedur Pelatihan dan Pengembangan Karyawan pada PT Bank Central Asia

\begin{tabular}{|c|c|c|}
\hline DIREKTUR & DEPARTEMEN YANG & DIREKTUR \\
\hline $\begin{array}{c}\text { DIVISI PELATIHAN DAN } \\
\text { PFNFFMRANGAN }\end{array}$ & MEMBUTHEAN & WAKIL DIREKTUR \\
\hline
\end{tabular}
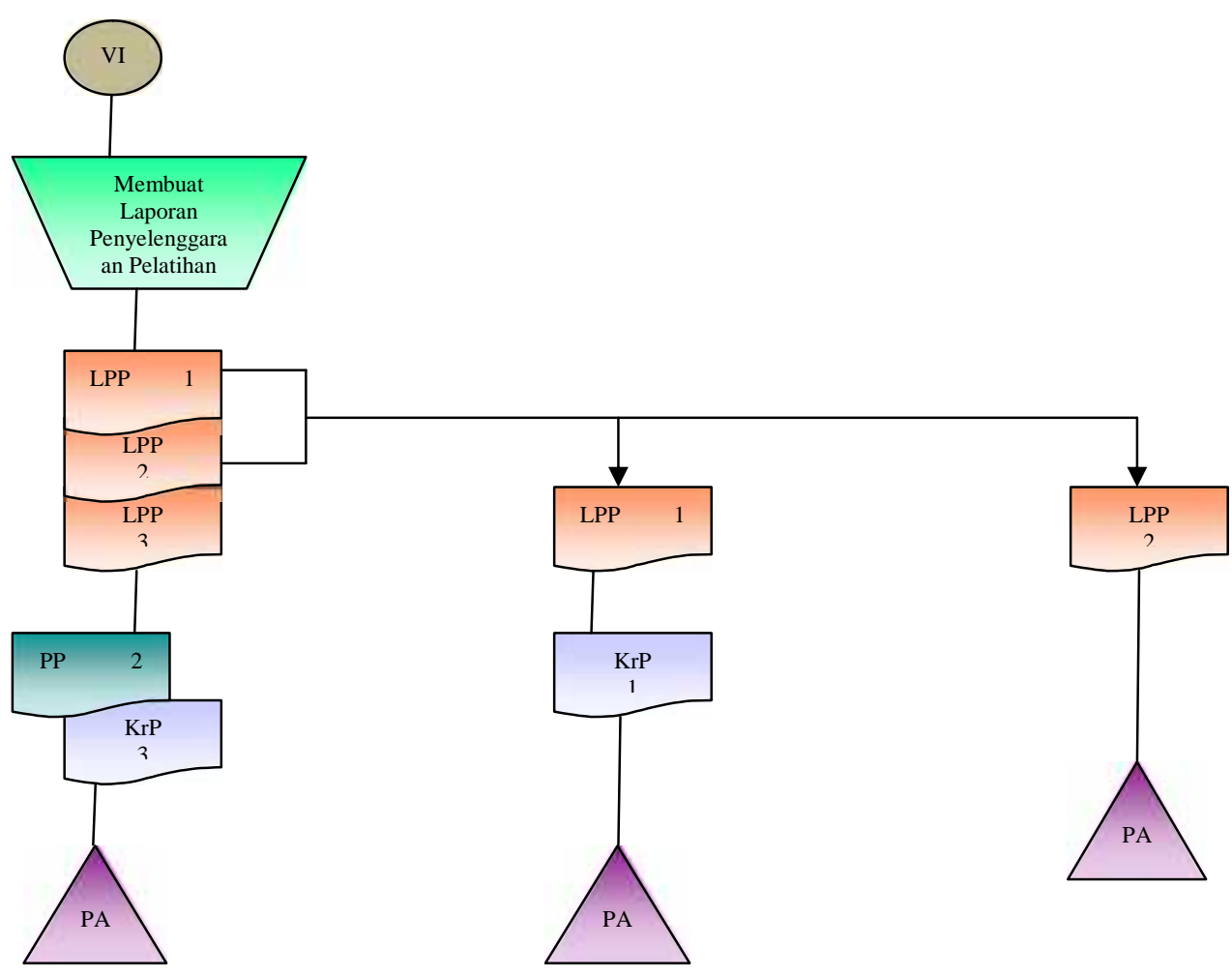
Keterangan: Formulir Laporan Penyelenggaraan Pelatihan (LPP); Formulir Program Pelatihan (PP); Formulir Kurikulum Pelatihan (KrP); Formulir Surat Ijin Praktek Kerja Lapangan (SIPKL)

Setelah membuat Sertifikat, Divisi Pelatihan dan Pengembangan membuat Laporan Penyelenggaraan Pelatihan (LPP), yang dibuat dalam 3 rangkap.LPP 1 untuk Departemen yang membutuhkan / $K W, K C U, K C P$, LPP 2 untuk Direktur, dan LPP 3 untuk Wakil Direktur / Divisi Pelatihan dan Pengembangan. User Divisi/ KW, KCU, KCP menerima LPP 1 dan KrP 1, kemudian LPP 1 disimpan dalam arsip permanen.

Direkturmenerima LPP 2 yang kemudian disimpan dalam arsip permanen. Divisi Pelatihan dan Pengembangan menerima LPP 3, kemudian PP 2 dan KrP 3, kemudian LPP 3 disimpan dalam arsip permanen.

Dari hasil penelitian diatas dapat diketahui bahwa semua pernyataan dalam variabel penelitian adalah valid dan reliabel. Valid karena nilai Corrected Item-Total Correlationuntuk semua butir pertanyaan pada setiap atribut lebih besar dari 0,3, dikatakan reliabel karena nilai Alpha Cronbach lebih besar dari 0,7. Hal ini menunjukkan bahwa kuesioner sebagai alat ukur tersebut layak untuk dilanjutkan ke analisis selanjutnya.

Untuk hasil uji asumsi diketahui bahwa nilai VIF sebesar 2,361 berarti 2,361 < 5 dengan demikian tidak terdapat multikolinieritas. Untuk uji heteroskedastisitas pada Tabel 1 terlihat titik - titik menyebar secara acak. Hal ini dapat disimpulkan bahwa tidak terjadi heteroskedastisitas.

Tabel 1. Hasil Uji Multikolinieritas dan Heteroskedatisitas

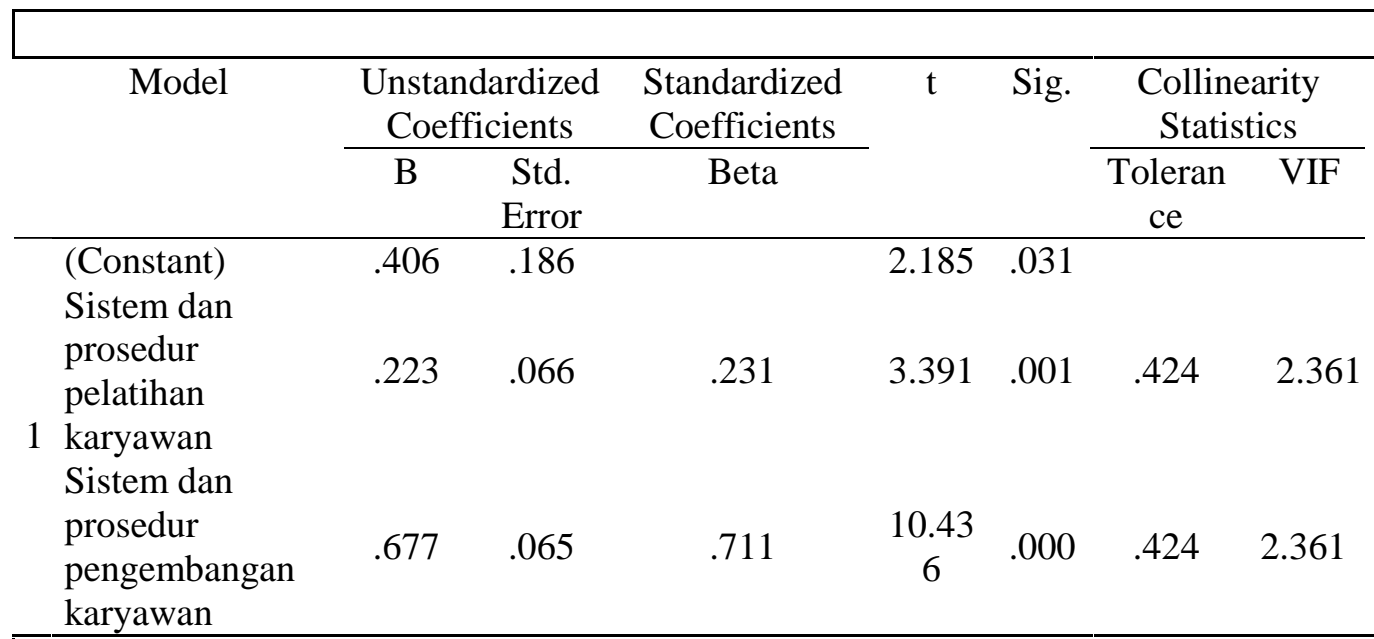

Tabel 2. Anova

\begin{tabular}{|c|c|c|c|c|c|c|}
\hline \multicolumn{7}{|c|}{ ANOVA $^{\mathrm{a}}$} \\
\hline Model & & $\begin{array}{l}\text { Sum } \\
\text { Squares }\end{array}$ & of $\mathrm{df}$ & Mean Square & $\mathrm{F}$ & Sig. \\
\hline \multirow{3}{*}{1} & Regression & 14.365 & 2 & 7.183 & 205.548 & $.000^{\mathrm{b}}$ \\
\hline & Residual & 3.390 & 97 & .035 & & \\
\hline & Total & 17.755 & 99 & & & \\
\hline
\end{tabular}


Hasil analisis regresi ganda untuk mengetahui pengaruh sistem dan prosedur pelatihan karyawan dan sistem dan prosedur pengembangan karyawan terhadap kualitas kinerja karyawan menghasilkan persamaan: $\mathrm{Y}=0,406+0,223 \mathrm{X} 1+0,677 \mathrm{X} 2$. Hasil pengujian hipotesis secara parsial $\left(\mathrm{Uji}_{1}\right.$ dan $\mathrm{H}_{2}$ ) menunjukkan bahwa nilai signifikansi variabel sistem dan prosedur pelatihan karyawan $\left(\mathrm{H}_{1}\right)$ adalah 0,000 (lebih kecil dari $\alpha=$ 5\%). Jadi, dapat disimpulkan bahwa ada pengaruh yang signifikan dari sistem dan prosedur pelatihan karyawan terhadap kualitas kinerja karyawan jika sistem dan prosedur pengembangan karyawan dianggap konstan dengan tingkat keyakinan 95\%, demikian juga nilai signifikansi variabel sistem dan prosedur pengembangan karyawan $\left(\mathrm{H}_{2}\right)$ adalah 0,001 (lebih kecil dari $\alpha=5 \%$ ). Jadi, dapat disimpulkan bahwa sistem dan prosedur pengembangan karyawan ada pengaruh terhadap kualitas kinerja karyawan dengan tingkat keyakinan $95 \%$.

Tabel 3. Analisis Regresi

\begin{tabular}{|c|c|c|c|c|c|c|c|}
\hline \multirow[t]{2}{*}{ Model } & \multicolumn{2}{|c|}{$\begin{array}{l}\text { Unstandardized } \\
\text { Coefficients }\end{array}$} & \multirow{2}{*}{$\begin{array}{c}\begin{array}{c}\text { Standardize } \\
\mathrm{d} \\
\text { Coefficients }\end{array} \\
\text { Beta }\end{array}$} & \multirow[t]{2}{*}{$\mathrm{t}$} & \multirow[t]{2}{*}{ Sig. } & \multicolumn{2}{|c|}{$\begin{array}{c}\text { Collinearity } \\
\text { Statistics }\end{array}$} \\
\hline & B & $\begin{array}{l}\text { Std. } \\
\text { Error }\end{array}$ & & & & $\begin{array}{c}\text { Tolera } \\
\text { nce }\end{array}$ & VIF \\
\hline \multirow{4}{*}{$\begin{array}{cc} & (\text { Constant }) \\
& \text { Sistem dan } \\
\text { prosedur pelatihan } \\
\text { karyawan } \\
1 & \text { Sistem dan } \\
\text { prosedur } \\
\text { pengembangan } \\
\text { karyawan }\end{array}$} & .406 & .186 & & 2.185 & .000 & & \\
\hline & & & & & & & \\
\hline & .223 & .066 & .231 & 3.391 & .000 & .424 & 2.361 \\
\hline & .677 & .065 & .711 & 10.436 & .000 & .424 & 2.361 \\
\hline
\end{tabular}

\section{PENUTUP}

Berdasarkan hasil pembahasan diatas dapat disimpulkan sebagai berikut: (1) Hasil pengujian validitas variabel sistem dan prosedur pelatihan karyawan dikatakan bahwa nilai corrected item total correction semua butir pernyataan pada setiap atribut lebih besar dari 0,3 , sehingga pernyataan tersebut adalah valid; (2) Hasil pengujian validitas variabel sistem dan prosedur pengembangan karyawan dikatakan bahwa nilai corrected item total correction semua butir pernyataan pada setiap atribut lebih besar dari 0,3 , sehingga pernyataan tersebut adalah valid; (3) Hasil pengujian validitas variabel kualitas kerja karyawan kepada PT. BCA dikatakan bahwa nilai corrected item total correction semua butir pernyataan pada setiap atribut lebih besar dari 0,3 , sehingga pernyataan tersebut adalah valid; (4) Ada pengaruh sistem dan prosedur pelatihan terhadap kualitas kerja karyawankepada PT. BCA mempunyai signifikansi sebesar 0,000 lebih kecil dari 0,05. Hal ini berarti sistem dan prosedur pelatihan karyawan dapat digunakan untuk mempengaruhi kualitas kerja karyawan kepada PT BCA Tbk di dengan tingkat keyakinan 95\%. (5) Ada pengaruh sistem dan prosedur pengembangan karyawan terhadap kualitas kerja karyawan kepada PT. BCA mempunyai signifikansi sebesar 0,001 lebih kecil dari 0,05 . Hal ini berarti sistem dan prosedur pengembangan karyawan dapat digunakan untuk 
mempengaruhi kualitas kerja karyawan kepada PT. BCA dengan tingkat keyakinan $95 \%$. (6) Ada pengaruh sistem dan prosedur pengembangan karyawan terhadap kualitas kerja karyawan kepada PT. BCA mempunyai signifikansi sebesar 0,000 lebih kecil dari 0,05. Hal ini berarti ada pengaruh sistem dan prosedur pelatihan dan pengembangan terhadap kualitas kerja karyawan pada PT. BCA dengan tingkat keyakinan 95\%.

Dengan melihat kesimpulan di atas, maka berikut ini akan disarankan kepada management PT. BCA sebagai berikut: (1) Berdasarkan pernyataan variabel pengaruh sistem dan prosedur pelatihan karyawan pada Bank BCA di Jakarta Pusat nilai rata-rata tertinggi sebesar 4,20 berada pada pernyataan Nilai Sikap (share)sedangkan nilai rata-rata terendah sebesar 4,06 berada pada pernyataan Nilai Keadilan dan Kepentingan Umum ( fair); (2) Berdasarkan nilai terendah penulis menyarankan sebaiknya perusahaan meningkatkan nilai keadilan dan kepentingan umum terhadap kualitas kerja karyawan yang ada di PT BCA; (3) Berdasarkan pernyataan variabel pengaruh sistem dan prosedur pengembangan karyawan pada Bank BCA nilai rata-rata tertinggi sebesar 4,077 berada pada pernyataan perilaku, sedangkan nilai rata-rata terendah sebesar 3,94 berada pada pernyataan fungsional; (4) Berdasarkan nilai terendah penulis menyarankan sebaiknya perusahaan meningkatkan fungsional agar para karyawan dapat melaksanakan tugas dan fungsi sesuai harapan nasabah; (5) Berdasarkan pernyataan variabel kualitas kerja karyawan pada PT. BCA nilai rata-rata tertinggi sebesar 4,13 berada pada pernyataan komunikasi (communication), sedangkan nilai rata-rata terendah sebesar 3,89 berada pada pernyataan berwujud (tangible). Berdasarkan nilai terendah penulis menyarankan sebaiknya perusahaan menyediakan berbagai fasilitas untuk memudahkan bagi karyawan dalam melayani nasabah.

\section{DAFTAR RUJUKAN}

Ambar Teguh Sulistiyani (2003) Manajemen Sumber Daya Manusia, Yogyakarta: Graha Ilmu

Amstrong, Garry (2000) Principles of Marketing, Eight Edition, New Jersey: Prentice Hall, Inc.

Aritonang R, Lerbin R. (2003) Riset Pemasaran: Teori dan Praktik. Bogor: Ghalia Indonesia

Arikunto, Suharsini (2002) Metode Penelitian: Suatu Pendekatan Praktek, Jakarta: Rhineka Cipta

Dessler, Gary (1997) Manajemen Sumber Daya Manusia. Jilid 1. Edisi Bahasa Indonesia. Jakarta: PT Prenhallindo

(2007) Manajemen Sumber Daya Manusia. Jilid 2. Edisi Bahasa Indonesia. Jakarta: PT. Prenhallindo

Henki Idris Issakh dan Siti Farzani Goenawan. (2000) Manajemen. Cetakan Pertama. Bekasi: Yayasan Rivo

Imam Gozali (2006) Aplikasi Analisis Multivariate Dengan Program SPSS. Semarang: Badan Penerbit Universitas Diponegoro Semarang.

Khotler Phillip (2009) Marketing Management. Millenium Edition North Western University. New Jersey: Precentice Hall Inc.

, (2000) Marketing Management. Millenium, University. New Jersey: Precentice Hall Inc. 
Mathis, Robert L. \& John H. Jackson, (2006) Manajemen Sumber Daya Manusia jilid II, Jakarta, Penerbit Salemba Empat.

Mc Leod, Raymond. (1995) Sistem Informasi Manajemen. (Diterjemahkan Hendra Teguh), Jakarta: PT. Bhuana Ilmu Populer . (2007) Sistem Informasi Manajemen. Jakarta: Prenhallindo.

Moekijat (1991) Pelatihan dan Pengembangan Sumber Daya Manusia. Edisi Pertama, Jakarta: Penerbit PT Bumi Aksara.

Mudrajat Kuncoro (2003) Metode Riset Untuk Bisnis dan Ekonomi. Jakarta: Erlangga

Mulyadi. (1989) Sistem Akuntansi. Edisi Kedua. Yogyakarta: Bagian Penerbitan Sekolah Tinggi Ekonomi YKPN. . (2001) Sistem Informasi Akuntansi. Edisi Kedua. Yogyakarta: Bagian Penerbitan Sekolah Tinggi Ekonomi YKPN.

Oemar Hamalik (1995) Kurikulum dan pembelajaran. Jakarta: Bumi Aksara.

Santoso,Singgih (2000) Statistik Parametik. Jakarta: Penerbit Elexmedia Computindo.

Schuller, S. Randall and Jackson. (1996) Manajemen Sumber Daya Manusia. Edisi Kelima. Jakarta: Erlangga.

Soebagio Atmodiwirio (2002) Manajemen Pelatihan. Cetakan Pertama. Jakarta: PT. Ardadizya Jaya

Singgaribun, Masri (2000) Metode Penelitian Survei. Jakarta: LP3ES

Sugiyono (2003) Metode Penelitian Bisnis. Cetakan Kelima, Bandung: CV Alpha Betha , (2007) Metode Penelitian Bisnis. Cetakan Keenam, Bandung: CV Alpha Betha

Supranto, J (2003) Statistik: Teori dan Aplikasi. Jilid 1, Edisi Kelima, Jakarta: Erlangga

Usman, Husaini (2003) Metode Penelitian Sosial. Jakarta : Bumi Aksara

Veithzal Rivai (2004) Manajemen Sumber Daya Manusia Untuk Perusahaan. Jakarta: PT Rajagrafindo Persada

Wijana, I Dewa Putu. (2002) Dasar-dasar Pragmatik. Yogyakarta : Andi.

Zaki Baridwan. (1993) Sistem Akuntansi Penyusunan Prosedur dan Metode. Yogyakarta: BPFE 